\title{
Pesticide Residues in Rhodesian Tobacco Attributable to Recommended Pest Control Practices*
}

\author{
by M. J.P. Shaw \\ Tobacco Research Board of Rhodesia, Salisbury, Rhodesia
}

The Tobacco Research Board of Rhodesia has for many years controlled the use of pesticides on tobacco in Rhodesia by a Pesticide Approval Scheme. The scheme imposes a series of tests and standards to be met by any new pesticide intended for use in Rhodesian tobacco culture. Tests are concerned with the biological efficiency of a pesticide, the resultant residues and smoking or manufacturing characteristics of the leaf and the effects of treatment on toxicity and tumourgenicity of smoke condensates. Thus, they take into account metabolites and degradation products of new pesticides likely to be recommended for use (3).

Table $x$ lists pesticides currently used in Rhodesian tobacco culture giving rates of application, targets of treatment and anticipated residues attributable to recommended pest control practices.

\section{Pesticides Applied in the Seedbeds}

Residues attributable to seedbed treatments have not been studied in detail. Generally, it has been assumed that because all seedbed leaves are lost in the field after transplanting, residues from seedbed treatments are unlikely to be detectable. Seedbeds are, however, used in a two-year rotation and large reserves of the more persistent pesticides like DDT do accumulate in the soil.

Seedbeds are routinely treated with a number of pesticides. Before making up the beds, the entire site is fumigated with methyl bromide or DD/MITC against nematodes, weeds, anthracnose (Colletotrichum tabacum) and other soil borne diseases.

Two weeks after seedlings have germinated, a drench of $0.23 \%$ DDT is applied at the rate of 1 litre/ $\mathrm{m}^{2}$ as a precautionary measure against cutworms (Agrotis ypsilon, A. segetum). The treatment results in about $12 \mathrm{ppm}$ in the $15 \mathrm{~cm}$ soil zone, xo or $11 \mathrm{ppm}$ of which is still present at the next application in a two-year rotation, assuming 5-10\% decomposition per year (6). In spite of this rate of accumulation, residue analyses have shown that the tobacco plant takes up negligible amounts. Ecologically, the treatment is undesirable and an alternative is being sought.

Routine, twice weekly sprays of thiram $(0.2 \%)$, manco-

\footnotetext{
* Presented at the 5th Internarional Tobacco Scientific Congress, Hamburg, Seprember 1970.

Research Paper No. 133.
}

zeb $(0.12 \%)$ or zineb $(0.1-0.2 \%)$ are recommended for the control of anthracnose (Colletotrichum tabacum) and copper oxychloride or oxysulphate $(0.25 \% \mathrm{Cu})$ sprays at intervals of 5-10 days are recommended for the control of wildfire (Pseudomonas tabaci), angular leaf spot ( $P$. angulata) and frogeye (Cercospora nicotineae).

\section{Pesticides Applied to the Soil in the Field}

Three weeks before tobacco is transplanted, each planting station is fumigated with a nematicide. Recommended amounts of EDB, DD or telone/EDB are usually injected with a fumigation gun. Significant increases in total halides of $1-3 \%$ of dry weight $(10,000-30,000$ ppm) following fumigation have been recorded (4), but the amount of increased halide attributable to bromine where EDB or telone/EDB is used is not known and is now being studied.

Aldrin and dieldrin are no longer used in association with tobacco culture in Rhodesla, but for many years it was routine practice to apply $0.56 \mathrm{~kg}$ active aldrin or dieldrin per hectare to planting holes as a precaution against attack by false wireworm and white grubs. Growers favoured dieldrin to aldrin and over a period of time this preference has led to an accumulation of dieldrin in some of our rotated tobacco soils.

Tincknell (5) has studied soil residue data for these two materials from various parts of America and Europe and has derived two simple expressions for the rates of decay of both materials in the soil (aldrin $=\frac{\mathrm{d}}{4}$ $(1-p)^{n-1}$, dieldrin $\left.=d(1-p)^{n}\right)$. These give estimated residues at the end of the $n^{\text {th }}$ year of a single application of $d$ kilograms active pesticide per hectare, where $p$, the proportion of decay per annum, is a constant of estimated value $0.16-0.29$ [Tinoknell (5)] or 0.28 [Edwards (2)] for temperate regions. Applications of dieldrin were made to tobacco fields in 3- or 4-year rotation at Kutsaga from 1955 to 1968 . Soils were sampled for dieldrin residues for the first time in 1969 (Table 2) and further samples will be taken each year to trace trends in decay. Analysis of the 1969 samples showed a much less rapid decay than expected from work done in temperate regions and estimates of the constant $p$ indicate a value of about $0.13(13 \%)$ in Table 2, theoretical rates of accumulation and decay 
Table 1. Rates, targets of treatment and anticlpated residues of pesticides recommended for use in Rhodesian tobacco culture.

\begin{tabular}{|c|c|c|c|c|c|}
\hline & Pesticide & Rate & $\begin{array}{l}\text { Appli- } \\
\text { cations }\end{array}$ & Target & $\begin{array}{l}\text { Anticipated } \\
\text { residues in } \\
\text { cured leaf }\end{array}$ \\
\hline 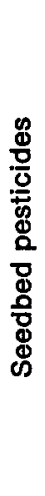 & $\begin{array}{l}\text { Nematicides } \\
98 \% \text { methylbromide } \\
\text { DD/MITC } \\
\text { Insectlcides } \\
\text { DDT } \\
\text { Funglcides } \\
\text { thiram } \\
\text { mancozeb } \\
\text { zineb } \\
\text { copper oxysulphate } \\
\text { copper oxychloride }\end{array}$ & $\begin{array}{l}1 \text { litre } 0.23 \% / \mathrm{m}^{2} \\
\text { drench } \\
0.2 \% \text { spray } \\
0.12 \% \text { spray } \\
0.1-0.2 \% \text { spray } \\
0.25 \% \text { Cu spray }\end{array}$ & $\begin{array}{l}1 \\
1 \\
1-2 \\
\text { UP } \\
\text { TO } \\
20\end{array}$ & $\begin{array}{l}\text { nematodes, weeds and } \\
\text { soil borne diseases } \\
\text { cutworms } \\
\text { wildfire, angular leaf } \\
\text { spot and frog-eye }\end{array}$ & nil \\
\hline 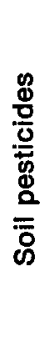 & $\begin{array}{l}\text { Nematicides } \\
\text { EDB }(41 \%) \\
\text { DD } \\
\text { telone/EDB } \\
\text { Insecticides } \\
\text { DDT } \\
\text { disulfoton } \\
\text { menazon }\end{array}$ & $\begin{array}{l}25 \mathrm{ml} 0.23 \% \text { /plant } \\
3 \mathrm{~g} 5 \% \text { gran./stn. } \\
6 \mathrm{~g} 5 \% \text { gran./stn. }\end{array}$ & $\begin{array}{l}1 \\
1 \\
1\end{array}$ & $\begin{array}{l}\text { M. javanica and } \\
\text { other nematodes }\end{array}$ & $\begin{array}{l}\left.\begin{array}{l}1 \% \\
3 \% \\
2 \%\end{array}\right\} \text { increase* } \\
\text { in halides } \\
\text { nil } \\
\text { nil } \\
<1.0 \mathrm{ppm}\end{array}$ \\
\hline 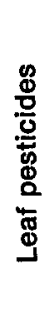 & $\begin{array}{l}\text { Fungicides } \\
\text { dinocap (A) } \\
\text { Insecticides } \\
\text { monocrotophos (C) } \\
\text { demeton-s-methyl (C) } \\
\text { dimethoate (A) } \\
\text { menazon (A) }\end{array}$ & $\begin{array}{l}0.25 \% \text { spray } \\
5-10 \mathrm{~kg} 2 \% \text { dust/ha } \\
0.075 \% \text { spray } \\
0.15 \% \text { spray } \\
0.15 \% \text { spray } \\
0.21 \% \text { spray }\end{array}$ & $\begin{array}{l}3 \\
3 \\
3 \\
1\end{array}$ & $\begin{array}{l}\text { powdery mildew } \\
\text { leafminers, budworms, } \\
\text { stinkbugs and aphids } \\
\text { aphids }\end{array}$ & $\begin{array}{l}<1.0 \mathrm{ppm} * \\
<0.5 \mathrm{ppm} \\
<1.0 \mathrm{ppm} \\
<0.5 \mathrm{ppm} \\
<5.0 \mathrm{ppm}\end{array}$ \\
\hline
\end{tabular}

* Tillet, 1966.

** Cole, 1963.
(A) Approved pesticides that have completed full series of pesticide approval scheme tests.

(C) Pesticides still under test but with no evidence for disapproval.

Table 2. 1969 dieldrin residues in soll zones to $30 \mathrm{~cm}$ in tobacco fields at Kutsaga, treated at intervals with $0.56 \mathrm{~kg}$ active dieldrin per ha, showing estimates of the constant (p) for rates of decay.

\begin{tabular}{|c|c|c|c|c|c|c|c|c|c|}
\hline \multirow{2}{*}{$\begin{array}{l}\text { Field } \\
\text { No. }\end{array}$} & \multirow{2}{*}{$\begin{array}{l}\text { Years } \\
\text { treated }\end{array}$} & \multirow{2}{*}{$\underset{\text { soil zone }}{X}$} & \multirow{2}{*}{$\begin{array}{l}\text { Y - } 1969 \\
\text { dieldrin } \\
\text { content }\end{array}$} & \multirow{2}{*}{$\begin{array}{c}\text { Mean } \\
\text { content } \\
\text { to } 30 \mathrm{~cm}\end{array}$} & \multicolumn{3}{|c|}{ Expected values for $p$} & \multirow{2}{*}{$\begin{array}{l}\text { Value of } X \\
\text { when } Y=0\end{array}$} & \multirow{2}{*}{$\begin{array}{c}\text { Extrapolated } \\
\text { mean } \\
\text { content }\end{array}$} \\
\hline & & & & & 0.13 & 0.16 & 0.29 & & \\
\hline & & $\mathrm{cm}$ & ppm & ppm & ppm & ppm & ppm & $\mathrm{cm}$ & ppm \\
\hline \multirow[t]{3}{*}{1} & 1955,1958 & $0-10$ & 0.35 & & & & & & \\
\hline & 1962,1966 & $10-20$ & 0.19 & 0.213 & 0.200 & 0.167 & 0.085 & 49.46 & 0.300 \\
\hline & & $20-30$ & 0.10 & & & & & & \\
\hline \multirow[t]{3}{*}{2} & 1956,1960 & $0-10$ & 0.46 & & & & & & \\
\hline & 1964,1968 & $10-20$ & 0.26 & 0.277 & 0.261 & 0.235 & 0.167 & 45.53 & 0.404 \\
\hline & - & $20-30$ & 0.11 & & & & & & \\
\hline \multirow[t]{3}{*}{3} & 1957,1961 & $0-10$ & 0.14 & & & & & & \\
\hline & 1965 & $10-20$ & 0.25 & 0.150 & 0.157 & 0.130 & 0.059 & 45.31 & 0.219 \\
\hline & & $20-30$ & 0.06 & & & & & & \\
\hline \multirow[t]{3}{*}{4} & 1959,1963 & $0-10$ & 0.33 & & & & & & \\
\hline & 1967 & $10-20$ & 0.14 & 0.187 & 0.207 & 0.183 & 0.117 & 41.69 & 0.285 \\
\hline & & $20-30$ & 0.09 & & & & & & \\
\hline
\end{tabular}


Figure 1. Theoretical rates of accumulation and decay of dieldrin (- - ) and aldrin plus dieldrin $(-0-)$ residues in solls treated every 4th year with $0.56 \mathrm{~kg}$ active dleldrin or aldrin per hectare.

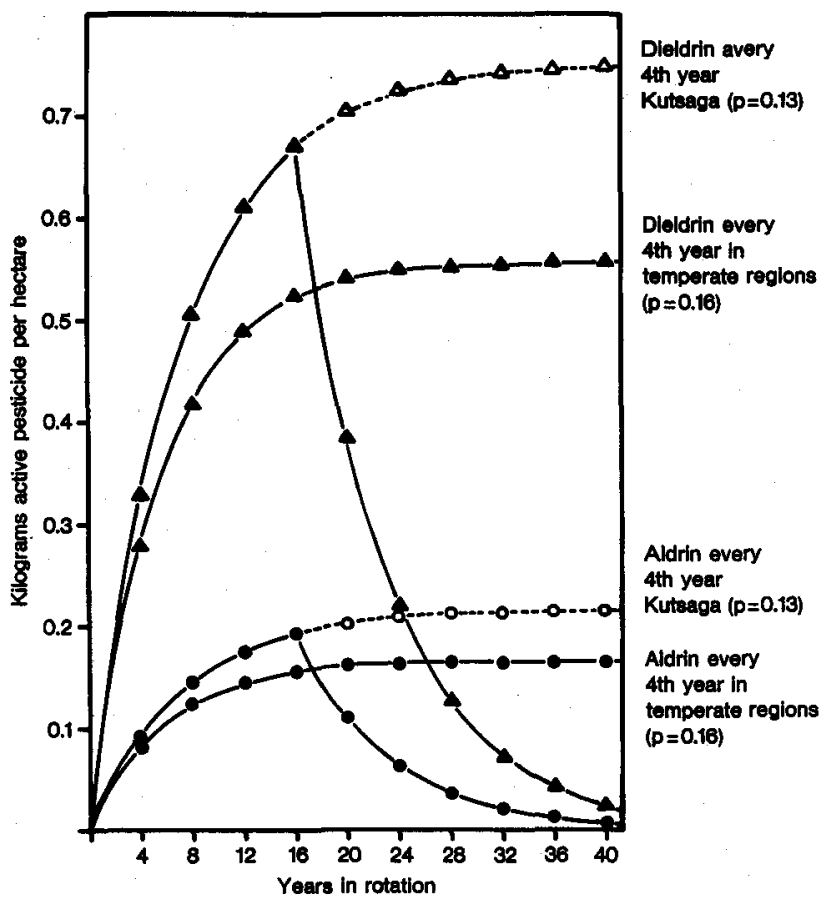

being illustrated in Figure $I$. If dieldrin content is plotted against log mean soil zone for samples from each field and regression lines fitted (Figure 2), it is evident that some dieldrin was probably in the soil below the sampled zone, possibly as far down as $50 \mathrm{~cm}$

Figure 2. Regressions of mean dieldrin residue content (ppm) on log mean soll zone sampled in tobacco flelds at Kutsaga In August 1969.

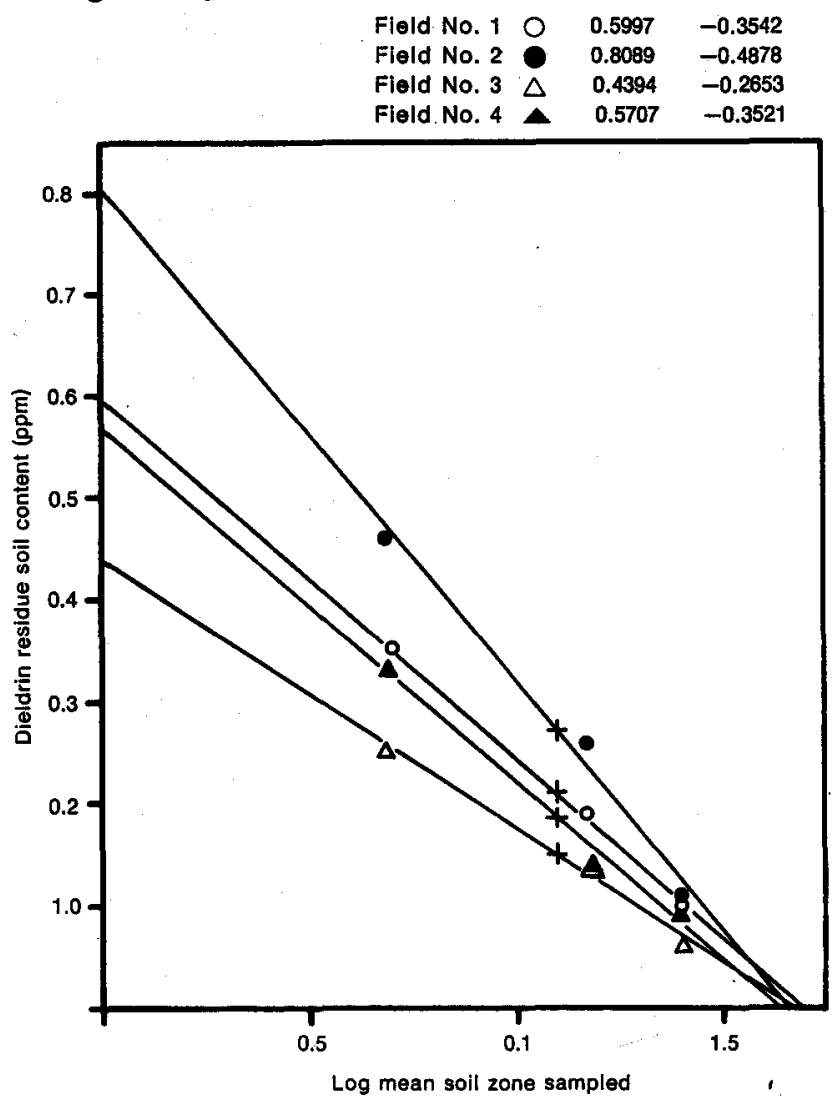

(Table 2). If the additional content is estimated from the regression lines and an extrapolated mean content to the estimated depth of permeation is calculated, it is apparent that the estimated value of $p=0.13$ may be extremely optimistic (Table 2). Future samples, which will be taken to a depth of $90 \mathrm{~cm}$, will improve the reliability of new estimates. The rate of transfer of dieldrin soil residues to tobacco plants under our conditions is currently under study. Preliminary results have shown that 0.2 to $0.3 \mathrm{ppm}$ dieldrin may be found in the first reapings of tobacco grown in rotated land treated every 4th year from 1957 with 0.56 active dieldrin per hectare but untreated in the current season (Table 2, field No. 3).

Aphids (Myzus persicae) and aphid borne virus diseases are not a serious problem in Rhodesia at the moment. Tobacco is now planted earlier in the season and most of it has probably completed the growth stage most favourable for aphid colonisation before the overwintering aphid population can take advantage of it. If aphids become a problem again, routine pre-planting applications of the granular aphicides disulfoton and menazon that resulted in negligible residues in cured leaf after recommended planting hole applications of $45 \mathrm{~kg}$ and $90 \mathrm{~kg}$ of $5 \%$ granules/ha respectively, may again become necessary.

After transplanting, as a precaution against cutworms in the field, about $25 \mathrm{ml}$ of a $0.23 \%$ DDT suspension is poured over the centre of each seedling so that the liquid trickles down and wets the surrounding soil. As a result of this treatment ( $1.05 \mathrm{~kg} / \mathrm{ha}), \mathrm{DDT}$ accumulates in the soil and $0.56 \mathrm{~kg} / \mathrm{ha}$ of one application is present before the next is applied in a $4 \mathrm{yr}$. rotation. None of this appears to be transferred to the tobacco plant, nevertheless, a less persistent treatment is urgently being sought.

\section{Pesticides Applied to the Leaves in the Field}

Dinocap fungicide is the only pesticide that is, in some instances, applied to leaf in the field as routine. Treatment is directed against powdery mildew, caused by Erysiphe cichoracearum and is applied as a $2 \%$ dust (10.I kg/ha) or as a $0.025 \%$ spray, starting about 6-8 weeks after planting. In recent years disease resistant varieties have been bred and this has led to a rapid decline in the use of this pesticide. Anticipated residues from treatment are less than 1 ppm (I).

Monocrotophos is the insecticide most frequently applied to the leaf. Sprays of $0.075 \%$ a. i. $(0.2-0.4 \mathrm{~kg}$ a. i./ha) are directed mainly against tobacco leaf miner (Pthorimeae. opercullela) but also give effective control of aphids, stinkbugs (Nazara spp.) and budworms (Heliothis armigera) if treatment is applied early enough. Residues are below measurable quantities. Three other recommended systemic aphicides are seldom used now. Residues are below limits of detection after applying $0.15 \%$ sprays of demeton-s-methyl or dimethoate $(0.2-0.4 \mathrm{~kg}$ a.i. $/ \mathrm{ha})$. Menazon sprays $(0.21 \%)(0.2-0.6$ $\mathrm{kg}$ a.i./ha) have produced residues of up to $5 \mathrm{ppm}$ per application but the material has met all standards 
required by the Pesticide Approval Scheme and is fully approved.

Until recently the Tobacco Research Board of Rhodesia's Pesticide Approval Scheme has been voluntary and although most growers undoubtedly adhered to it very closely, for they were well aware of the dangers to the industry of not doing so, legislation has now been introduced that will render tobacco treated with pesticides other than in accordance with Tobacco Research Board recommendations unsaleable, and liable to destruction without compensation. Pesticide residues in the crop offered for sale will be monitored to ensure that the legislation is functional.

\section{SUMMARY}

The use of pesticides on tobacco in Rhodesia is controlled by legislation that prevents the sale of tobacco treated with unscheduled pesticides. Residues attributable to seedbed treatments have not been studied in detail; the scheduled pesticides that can be applied to the soil and the leaf in the field have been considered more fully. Although no longer permitted for use, aldrin and dieldrin soil residues from previous treatments are more persistent in tropical sandy soils than in soils of the temperate regions and small amounts of background dieldrin are taken up by tobacco grown in these soils. Uptake of DDT is negligible and very little disulfoton or menazon applied to the soil is found in cured leaf. The pesticides that are permitted for application to the leaf result in residues of less than I ppm except menazon which results in a residue of up to $5 \mathrm{ppm}$.

\section{ZUSAMMENFASSUNG}

In Rhodesien wird die Verwendung von Pestiziden bei Tabak durch Gesetze geregelt, die den Verkauf von Tabak verbieten, wenn dieser mit amtlich nicht zugelassenen Pestiziden behandelt worden ist. Rückstände, die auf Behandlung im Saatbeet zurückzuführen sind, wurden bisher im einzelnen kaum untersucht; hingegen liegen mehr Ergebnisse iber Reste von amtlich zugelassenen Pestiziden vor, die zur Behandlung der Böden und der Pflanzen im Tabakfeld verwendet werden können. Aldrin und Dieldrin werden zwar nicht mehr angewendet, die Rückstände dieser Mittel aus früheren Behandlungen bleiben in tropischen sandigen Böden aber nachhaltiger persistent als in den Böden der gemäßigten Zonen und werden von den Tabakpflanzen entsprechend aus den Böden aufgenommen. Die Aufnahme von DDT ist zu vernachlässigen. Im getrockneten Blatt finden sich nur sehr geringe Reste an Disulfoton und Menazon, wenn diese Mittel dem Boden zugesetzt werden. Pestizide, die auf Blattabak angewendet werden dürfen, führen nur zu Rückständen von weniger als I ppm. Nur bei Menazon fanden sich Rückstände bis zu 5 ppm.

\section{RESUME}

En Rhodésie l'usage de pesticides pour le tabac est controlé par une loi qui interdit la vente du tabac traité avec des pesticides non prévus. On n'a pas étudié en détail les résidus imputables aux traitements des graines; on a étudié d'avantage les pesticides autorisés pour le traitement du sol et du feuillage.

Quoique l'aldrin et le dieldrin ne sont plus autorisés, on décèle des résidus dans le sol dûs à des traitements antérieurs, qui semblent plus persistants dans les sols tropicaux sablonneux que dans les sols des régions tempérées, aussi on découvre des quantités minimes de dieldrin résiduel absorbé par le tabac qui pousse sur ces sols. La quantité de DDT absorbée est négligeable et on ne trouve que très peu du disulfoton ou du menazon, appliqués au sol, dans les feuilles séchées. Les pesticides autorisés à être appliqués sur les feuilles ne se retrouvent $\mathrm{qu}^{\prime} \mathrm{en}$ quantités résiduelles inférieures à I ppm excepté le ménazon qui donne un résidu jusqu'à $5 \mathrm{ppm}$.

\section{REFERENCES}

1. Cole, J. S.: Control of tobacco powdery mildew caused by Erysiphe cichoracearum DC by foliar sprays; Rhod. J. Agric. Res. 1 (1963) 65-70.

2. Edwards, C. A.: Insecticide residues in soils; Residue Reviews 13 (1966) 83-132.

3. Shaw, M. J. P.: Rhodesian moves anticipated tobacco pesticide tesidue problem; Tobacco N. Y. 170 (1970) $\times 5$.

4. Tillet, E. R.: The effect of fumigation and sources of nitrogen on the yield, quality and composition of flue-cured tobacco in Rhodesia; Proc. 4th Int. Tobacco Scientific Congress, Athens, 1966, 127-134.

5. Tincknell, R. C.: Residues in agricultural soils derived from aldrin and dieldrin applications; I.U.P.A.C. Symposium on the Chemical Control of the Human Environment, Johannesburg, S. Africa, $1969,25 \mathrm{p}$.

6. Yu, S. Kagan, Fudel-Ossipova, S. I., Knaikina, B. J., Kugminskaya, U. A., and Konton, S. D.: On the problem of the harmful effect of DDT and its medhanism of action; Residue Reviews 27 (1969) $43-79$.

The author's address:

Tobacco Research Board of Rhodesia, P.O. Box 19o9, Salisbury, Rhodesia. 